\title{
Effect of molybdenum and tungsten on the reduction of nitrate in nitrate reductase, a DFT study
}

\author{
Uzma Habib $^{1^{*}}$ and Matthias Hoffman ${ }^{2}$
}

\begin{abstract}
The molybdenum and tungsten active site model complexes, derived from the protein $\mathrm{X}$-ray crystal structure of the first W-containing nitrate reductase isolated from Pyrobaculum aerophilum, were computed for nitrate reduction at the COSMO-B3LYP/SDDP//B3LYP/LanL2DZ(p) energy level of density functional theory. The molybdenum containing active site model complex (Mo-Nar) has the largest activation energy $(34.4 \mathrm{kcal} / \mathrm{mol})$ for the oxygen atom transfer from the nitrate to the metal center as compared to the tungsten containing active site model complex (W-Nar) $(12.0 \mathrm{kcal} / \mathrm{mol})$. Oxidation of the educt complex is close to thermoneutral $(-1.9 \mathrm{kcal} / \mathrm{mol})$ for the Mo active site model complex but strongly exothermic $(-34.7 \mathrm{kcal} / \mathrm{mol})$ for the $\mathrm{W}$ containing active site model complex, however, the $\mathrm{M}^{\mathrm{Vl}}$ to $\mathrm{M}^{\mathrm{IV}}$ reduction requires equal amount of reductive power for both metal complexes, Mo-Nar or W-Nar.
\end{abstract}

Keywords: Nitrate reductase, DFT studies, Molybdenum, Tungsten

\section{Background}

Molybdenum and tungsten are the only $4 \mathrm{~d}(\mathrm{Mo})$ and $5 \mathrm{~d}$ (W) transition metals prefer to be essential for biological systems. Mononuclear enzymes containing Mo or $\mathrm{W}$ at their active sites generally catalyze oxygen atom transfer reactions $[1,2]$. Despite the high similarity between the chemical properties of Mo and W, W-containing enzymes are by far less common. Mo-containing enzymes are found in almost all forms of life [1], whereas $\mathrm{W}$-containing enzymes seem to be popular for organisms such as hyperthermophilic archaea that live in extreme environments [2]. However, W-containing enzymes have also been found in organisms that do not need extreme conditions [3-5], suggesting a more important role for tungsten [6].

Mononuclear enzymes contain a cofactor that comprises metallopterin (MPT) or some of its nucleotide variants, each of which is coordinated to Mo or W with an enedithiolene motif. Based on the active site structure

\footnotetext{
*Correspondence: uzma.habib@rcms.nust.edu.pk

${ }^{1}$ Research Center for Modeling and Simulation (RCMS), National

University of Science and Technology (NUST), H-12, Islamabad, Pakistan

Full list of author information is available at the end of the article
}

and type of reaction they catalyze, these mononuclear MPT containing enzymes have been grouped into three subfamilies (Fig. 1), xanthine oxidase family, sulfite oxidase family, and DMSO (dimethylsulfoxide) reductase family [1].

Nitrate reductases (NRs) play key roles in the first step of biological nitrogen cycles [7-9] i.e., assimilatory ammonification (to incorporate nitrogen into biomolecules), denitrification (to generate energy for cellular function) and dissimilatory ammonification (to dissipate extra energy by respiration). They always catalyze the reduction of nitrate to nitrite, and have been classified into three groups, assimilatory nitrate reductases (Nas), respiratory nitrate reductases (Nar) and periplasmic nitrate reductases (Nap). Nas belongs to the sulfite oxidase family and is located in the cytoplasm [10]. It is the first enzyme of a reduction sequence for nitrogen incorporation into the biomass that maintains the bioavailability of nitrate to plants, algae, fungi, archaea and bacteria $[11,12]$. Dissimilatory nitrate reductases, Nar and Nap belong to the DMSO reductase family of mononuclear MPT containing molybdo-enzymes. They are linked to respiratory electron transport systems and are located in the membrane and periplasm, respectively. They catalyze 


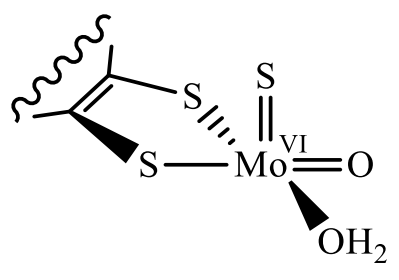

Xanthine Oxidase Family

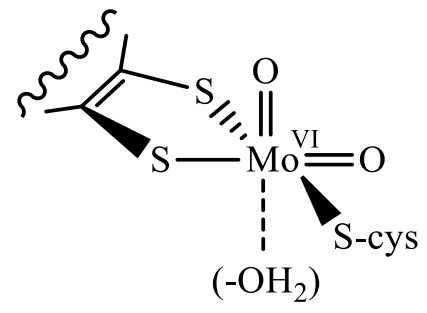

Sulfite Oxidase Family

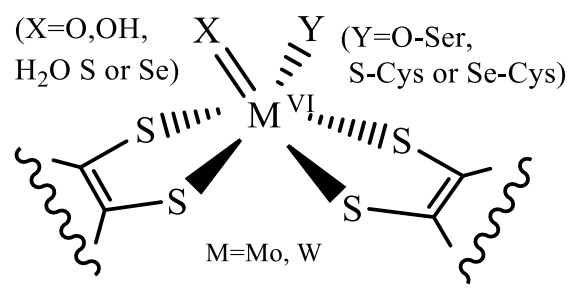

DMSO Reductase Family

Fig. 1 Active site composition of subfamilies of mononuclear Mo/W enzymes

the first step of the catabolic, anaerobic respiration pathway in bacteria and archaea [14].

Nitrate reduction, catalyzed by membrane bound respiratory nitrate reductase (Nar), is an important step of the denitrification in the anaerobic respiratory pathways employed by a diverse group of bacteria and archaea [13]. Nar was found to contain a Mo cofactor in all microbes from which it was isolated and belongs to the DMSO reductase family [14]. In general, Nar becomes inactive by the addition of tungstate $\left(\mathrm{WO}_{4}{ }^{2-}\right)$ to the growth medium [15], although due to similar chemical properties W can replace Mo as the active site metal and cannot only retain but increase its catalytic activity in $E$. coli TMAO reductase [16], the Desulfovibrio alaskensis formate dehydrogenase [17] and the Rhodobactercapsulatus DMSO reductase [18]. However, recently the nitrate reductase (Nar) from the hyperthermophilic denitrifying archaeon Pyrobaculum aerophilum has been shown to retain its activity even at a tungsten rich environment [19].

Pyrobaculum aerophilum, a hyperthermophilic archaeon, is naturally exposed to high levels of tungsten, a heavy metal that is abundant in high temperature environments. Tungsten was reported to stimulate the growth of several mesophilic methanogens and some mesophilic and thermophilic bacteria [14]. The growth of P. aerophilum also depends on the presence of tungstate in the growth medium which suggests the involvement of tungstoenzymes in essential metabolic pathways [20].

Pyrobaculum aerophilum is the only hyperthermophilic archaeon isolated that reduces nitrate via a membrane bound respiratory nitrate reductase (Nar) [20]. Nar purified from $P$. aerophilum grown in the absence of added molybdate $\left(\mathrm{MoO}_{4}{ }^{2-}\right)$ and with $4.5 \mu \mathrm{M}$ tungstate $\left(\mathrm{WO}_{4}{ }^{2-}\right)$ is a tungsten containing enzyme, which is identical to Mo-Nar [21] (previously isolated from P. aerophilum), indicating that either metal can serve as the active site ion. The crystal structure is similar to the previously reported Nar from E. coli [22], a heterodimeric enzyme termed as NarGH where NarG hosts the metal (Mo or $\mathrm{W})$ catalytic site. The metal is coordinated by two metallopterin guanine dinucleotide (bis-MGD) ligands, a carboxyl group of $\mathrm{Asp}_{222}$ and a water molecule. The NarH component possesses an iron-sulfur $(\mathrm{FeS})$ redox active subunit [19].

NarGH reduces nitrate to nitrite, changing the oxidation state of metal from +IV to +VI. Two electrons and two protons are required for the reductive half reaction, resulting in the formation of a water molecule and a nitrite ion (Eq. 1).

$$
\mathrm{NO}_{3}^{-}+2 \mathrm{H}^{+}+2 \mathrm{e}^{-} \rightleftharpoons \mathrm{NO}_{2}^{-}+\mathrm{H}_{2} \mathrm{O} \text {. }
$$

The active site of dissimilatory nitrate reductase (Desulfovibrio desulfuricans), in the reduced state contains a Mo atom bound by two metalopterin dithiolene ligands and a cysteinate residue. An experimental study on small model complexes demonstrates that nitrate reduction by primary (direct) oxo transfer [23] is a feasible reaction pathway (Fig. 2) [24].

Here we present a density functional theory (DFT) study on model complexes derived from the protein X-ray crystal structure of $P$. aerophilum [19] nitrate reductase (Nar). The purpose of the study was to investigate (i) the effect on the reduction of nitrate when $\mathrm{W}$ replaces Mo at the active site, (ii) the energy barriers on the potential energy surface and (iii) the reason for the activity loss of Nars (respiratory nitrate reductase) in the presence of W.

\section{Computational details}

All geometries were optimized using Gaussian 09 with the hybrid density functional B3LYP [25] and the LANL2DZ basis set [26-29] augmented by polarization functions on sulfur atoms $(\zeta=0.421)$ [30]. The starting nitrate complex geometries for transition state searches were generated by shortening and lengthening of forming and breaking bonds, respectively. Frequency calculations proved transition states to have exactly one imaginary 


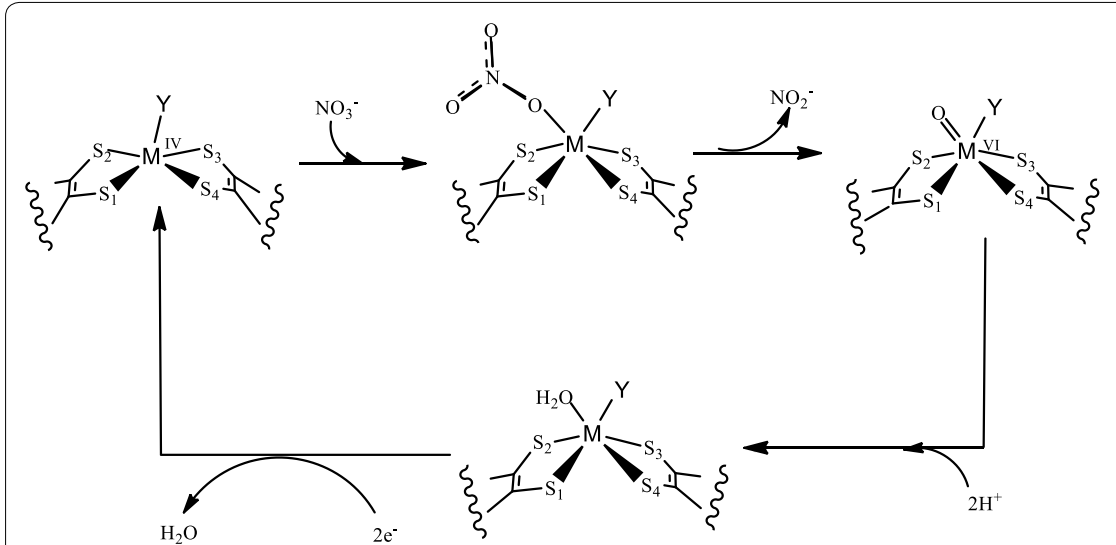<smiles>CC(C)(C)NSC1=C(COP(=O)(O)O)C2Nc3c(nc(N)[nH]c3=O)NC2O1</smiles>

Metalopterindithiolene cofactor, $\mathrm{R}$ absent or a nucleotide

Fig. 2 Schematic description of the proposed mechansim [1] for the nitrate reduction, where M=Mo and $Y=S-C y s$. Also the metalopterin dinucleotide cofactor is shown

frequency with the correct transition vector. Single point energies were computed with the B3LYP functional and the Stuttgart-Dresden effective core potential basis set (SDD) [31, 32] augmented by polarization functions for all atoms except Mo, $\mathrm{W}$ and $\mathrm{H}(\zeta=0.600,1.154,0.864$, and 0.421 for $\mathrm{C}, \mathrm{O}, \mathrm{N}$, and $\mathrm{S}$, respectively) [30]. Selfconsistent reaction field (SCRF) computations were performed on the optimized geometries to model the protein surrounding the active site by a conductor like polarizable continuum method (CPCM) [33] as implemented in Gaussian 09 [34, 35]. Default Gaussian 03 parameters were used for the evaluation of solute-solvent dispersion and repulsion interaction energies [36, 37], and solute cavitation energy variations [38]. The molecular cavity was specified using a minimum radius (RMin) of $0.5 \AA$ and an overlap index (OFac) of 0.8 [39].

\section{Active site models}

Two types of active site models were designed on the basis of the protein X-ray crystal structure of $P$. aerophilum (PDB ID: 1R27) [19] only differing in the metal center, a containing Mo and $\mathbf{b}$ containing $\mathrm{W}$ at the active site. These active site models include the metal center coordinated by two enedithiolene moieties of the pterin molecules, by $\mathrm{Asp}_{222}$ and by $\mathrm{H}_{2} \mathrm{O}_{8538}$. $\mathrm{His}_{546}, \mathrm{Asn}_{52}$, $\mathrm{Tyr}_{220}, \mathrm{Gly}_{549}$ and $\mathrm{Val}_{578}$ residues were also included in the model complexes as they may influence the catalytic reaction due to their proximity to the metal center. Hydrogen atoms were added manually. $\mathrm{His}_{546}$ and $\mathrm{Gly}_{549}$ residues form hydrogen bonds to the ionized $\mathrm{Asp}_{222}$ preventing it to rotate and become a bidentate ligand which then would block the substrate binding site. $\mathrm{Asn}_{52}$ was included as its distance of $3.9 \AA$ from the metal center suggests that it is suitable for substrate coordination [19]. During the optimizations, alpha $(\alpha)$ carbon atoms and nitrogen atoms attached to the beta $(\beta)$ carbon atoms of $\mathrm{His}_{546}, \mathrm{Asn}_{52}, \mathrm{Tyr}_{220}$ and $\mathrm{Asp}_{222}$ were kept fixed to their crystal structure positions to mimic the steric constraints by the protein matrix. Carbon atom $\mathrm{C}_{7}$ and the nitrogen atom attached to carbon atom $\mathrm{C}_{5}$ were kept fixed for residue $\mathrm{Gly}_{549}$. The MPT ligands were truncated at the pyran rings and oxygen atoms of these pyran rings were also kept fixed (Fig. 3).

First, hydrogen atoms were geometry optimized applying one negative overall charge (assuming Mo/W at the +VI oxidation state), keeping all heavy-atoms fixed at their positions. The resulting geometries served to generate the different starting geometries needed for computing the mechanism for nitrate reduction.

The starting geometries for the substrate and product complexes are generated by slight distortion of $\mathrm{M}-\mathrm{O}$ and $\mathrm{O}-\mathrm{NO}_{2}$ in the optimized transition state geometries, $\mathbf{6 a}$ and $\mathbf{6 b}$. Geometries with slightly elongated $\mathrm{M}-\mathrm{O}$ distance and reduced $\mathrm{O}-\mathrm{NO}_{2}$ distance are considered as the starting geometries for the optimization of $\mathbf{5 a}$ and $\mathbf{5 b}$ educt-substrate complexes whereas reduced $\mathrm{M}-\mathrm{O}$ distance and elongated $\mathrm{O}-\mathrm{NO}_{2}$ distance are considered as the starting geometries for the optimization of $\mathbf{7 a}$ and $\mathbf{7 b}$ product complexes. The geometry optimizations of these distorted geometries directly lead to complexes, $\mathbf{5 a} / \mathbf{5 b}$ and $7 \mathbf{a} / 7 \mathbf{b}$.

\section{Results}

\section{Optimized active site model complexes}

The protein X-ray crystal structure of $P$. aerophilum Nar from the PDB data base (PDB ID: 1R27) [19] shows that at the active site the metal is coordinated by two metallopterin guanine dinucleotide (bis-MGD) ligands, a carboxyl group of $\mathrm{Asp}_{222}$ and a water molecule [19]. However, the distance of the oxygen atom $\left(\mathrm{O}_{\text {wat }}\right)$ of this 


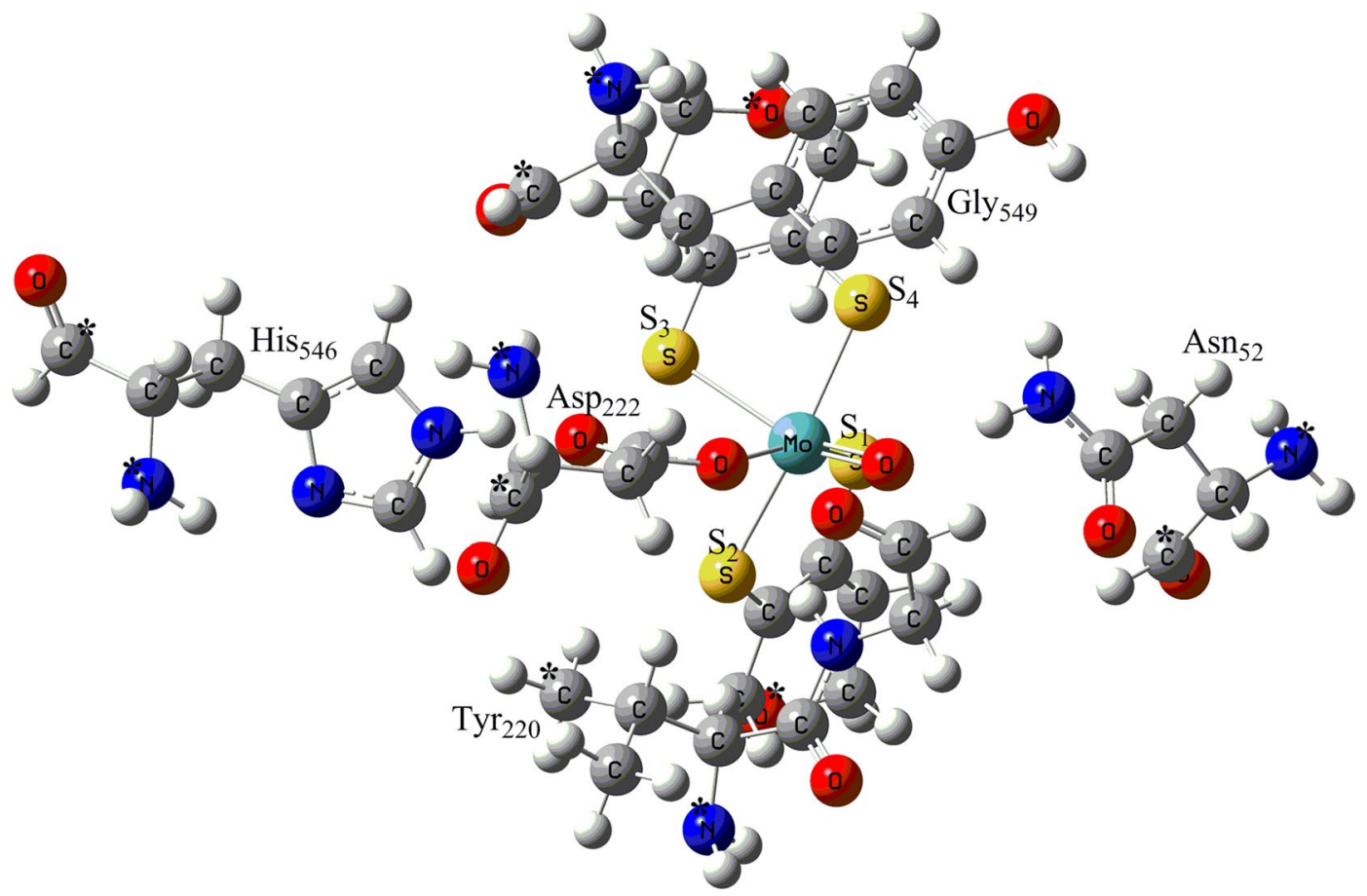

Fig. 3 Optimized oxidized active site model of Mo-Nar. Atoms labeled $\left(^{*}\right)$ were kept fixed at their X-ray crystal structure positions

coordinated water molecule from the metal center is $1.87 \AA$ which neither falls in the range expected for metal oxide (1.71-1.75 $\AA$ ) [ 40,41$]$, nor for water $(2.0-2.3 \AA \AA)$ [42] ligands. Also, the distance between $\mathrm{O}_{\text {wat }}$ and oxygen of $\operatorname{Asp}_{222}\left(\mathrm{O}_{\text {Asp }}\right)$ is $1.59 \AA$, which is only $0.1 \AA \AA$ longer than the typical peroxo $\mathrm{O}-\mathrm{O}^{-}$bond length $(1.49 \AA$ ) .

We have optimized three active site model complexes to clarify the nature of this oxo species; 1 (oxidation state of $\mathrm{Mo} / \mathrm{W}$ is $+\mathrm{IV}$, overall charge is -1 ) contains a water molecule, 2 (oxidation state of $\mathrm{Mo} / \mathrm{W}$ is $+\mathrm{V}$, overall charge is -1 ) contains a hydroxide ligand and 3 (oxidation state of $\mathrm{Mo} / \mathrm{W}$ is $+\mathrm{VI}$, overall charge is -1 ) contains an oxide $\left(\mathrm{O}_{1}\right)$ group attached to the metal (Fig. 4).

Geometry optimizations of active site model complexes 1,2 and 3 results in distinctively different geometrical parameters of the metal coordination site relative to the protein X-ray crystal structure geometry of NarGH [19]. Optimized geometry data for the model complexes 1a with $M=$ Mo $(\mathbf{1 b}, M=W)$ show that the dithiolenes are twisted less against each other as the $\mathrm{S}_{1}-\mathrm{S}_{2}-\mathrm{S}_{3}-\mathrm{S}_{4}$ dihedral angle decreases from $-18.3^{\circ}$ to $-6.4^{\circ}$ for $1 \mathrm{a}\left(-2.5^{\circ}\right.$ for $\mathbf{1 b})$ i.e., the coordination geometries are nearly trigonal prismatic (Tables 1, 2). Bond distances between the metal center, $M$ and the dithiolene sulfur atoms decreases from $\sim 2.455$ to $\sim 2.393 \AA$ ( $2.384 \AA$ \& $)$ when comparison is made with the protein X-ray crystal structure (Fig. 5; Tables 1, 2). Elongated bond distances for $\mathrm{M}-\mathrm{O}_{\text {wat }}$ [from
1.874 to $2.335 \AA$ ( $(2.286 \AA \hat{)})$ ] and $\mathrm{M}-\mathrm{O}_{\text {Asp }}$ [from 1.97 to $2.142 \AA \tilde{A}(2.122 \AA \hat{)})]$ are computed. But the main difference lies in the Mo-S $\mathrm{S}_{2}$ bond distance (from 2.537 to $2.387 \AA$ ) (Fig. 5; Tables 1, 2), in the bond angles between the $\mathrm{O}_{\text {Asp }}$, $\mathrm{M}$ and $\mathrm{O}_{\text {wat }}$ [from $49^{\circ}$ to $66^{\circ}\left(66^{\circ}\right)$ ], and in the distance between the two oxygen atoms, $\mathrm{O}_{\text {Asp }}-\mathrm{O}_{\text {wat }}$ [from 1.596 to $2.428 \AA ̊(2.392 \AA))]$.

Distorted trigonal prismatic geometries result from geometry optimizations of oxidized model complexes 2a (2b). Optimized data show changes in the $\mathrm{S}_{1}-\mathrm{S}_{2}-\mathrm{S}_{3}-$ $\mathrm{S}_{4}$ dihedral angles from $-18.3^{\circ}$ to $15.1^{\circ}\left(20.2^{\circ}\right)$ and in the M-S bond distances from $\sim 2.455$ to $\sim 2.420 \AA$ ( 2.417 $\AA$ ) as compared to the protein X-ray crystal structure (Fig. 5; Tables 1, 2). Bond distances between $\mathrm{M}-\mathrm{O}_{\text {Asp }}$ and $\mathrm{M}-\mathrm{OH}$ are increased from 1.97 to $2.145 \AA$ ( $2.113 \AA$ ) and from 1.874 to $1.990 \AA \AA$ (1.973 $\AA$ ), respectively. $\mathrm{O}_{\mathrm{Asp}}-\mathrm{O}_{\mathrm{OH}}$ bond distance is increased from 1.596 to $2.458 \AA$ (2.439 $\AA$ ) and the bond angle between $\mathrm{O}_{\text {Asp }}, \mathrm{M}$ and $\mathrm{O}_{\mathrm{OH}}$ is increased from $49^{\circ}$ to $72.8^{\circ}\left(73.2^{\circ}\right)$.

Distorted octahedral coordination geometries result from geometry optimizations of oxidized model complexes 3a (3b).Optimized data shows increase in the $\mathrm{S}_{1}-\mathrm{S}_{2}-\mathrm{S}_{3}-\mathrm{S}_{4}$ dihedral angles [from $-18.3^{\circ}$ to $-43.7^{\circ}$ $\left(-42.1^{\circ}\right)$ ] and in the $\mathrm{M}-\mathrm{S}$ bond distances [from $\sim 2.455$ to $\sim 2.474 \AA$ ( $(\sim 2.461 \AA$ ) $)$. One M-S bond is significantly longer than the other three. However, it is the $\mathrm{M}-\mathrm{S}_{2}$ bond $(2.537 \AA)$ in the X-ray structure while it is the $\mathrm{M}-\mathrm{S}_{3}$ bond 


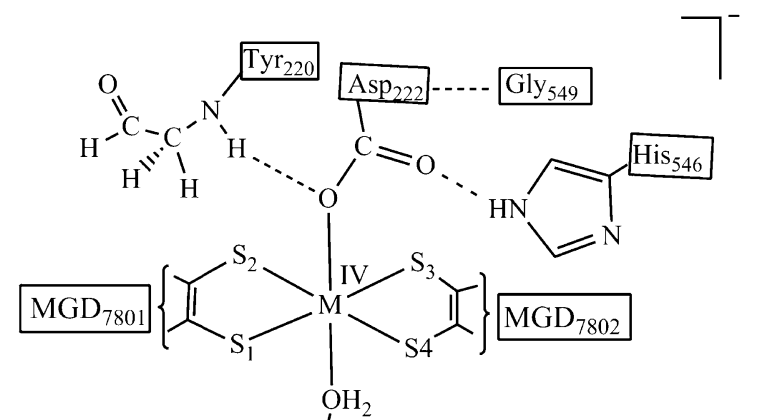<smiles>OCNC1CCC1</smiles>

a: $\mathrm{M}=\mathrm{Mo}$

b: $M=W$<smiles>CCCC1CCCC1</smiles>

1

2

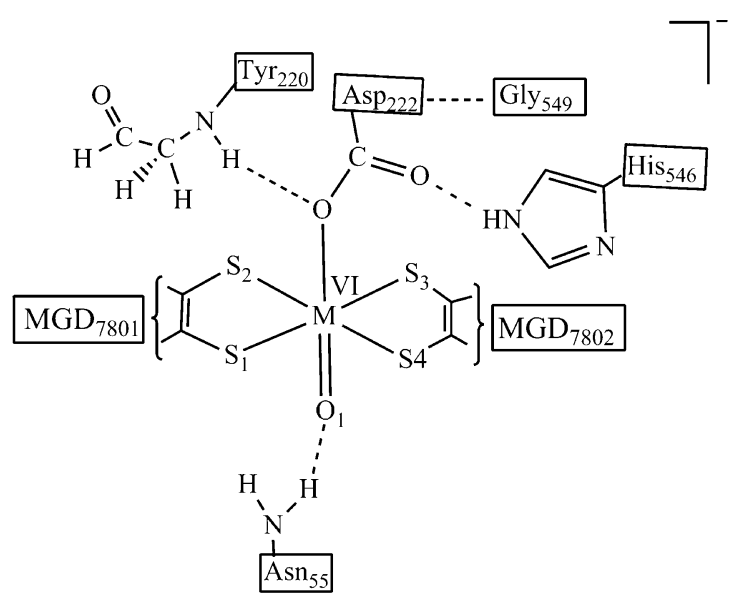

3

Fig. 4 The chemical structure of the active site model complexes $\mathbf{1}$ and $\mathbf{2}$ derived from the protein X-ray crystal structure of Nar (PDB ID 1R27) [19]

[2.591 Á (2.549)] (Fig. 5; Tables 1,2) in the optimized oxidized model complexes. These sulfur atoms $\left(S_{2}\right.$ and $S_{3}$, respectively) are at the trans position relative to the oxo ligand, a trans-influencing ligand which causes the elongation of the $\mathrm{M}-\mathrm{S}$ bonds.

Increased bond angles between the $\mathrm{O}_{\text {Asp }}, \mathrm{M}$ and $\mathrm{O}_{1}$ [from $49^{\circ}$ to $88^{\circ}\left(88^{\circ}\right)$ ], and distances between the two oxygen atoms, $\mathrm{O}_{\mathrm{Asp}}-\mathrm{O}_{1}$ [from 1.596 to $2.684 \AA$ ( $(2.647 \AA \hat{)})$ ] are computed in complexes 3a (3b). Slightly elongated $\mathrm{M}-\mathrm{O}_{\text {Asp }}$ distances [from 1.97 to $2.083 \AA$ (2.04 $\hat{\text { ) }}$ ] and shortened $\mathrm{M}-\mathrm{O}_{1}$ distances [from 1.874 to $1.755 \AA$

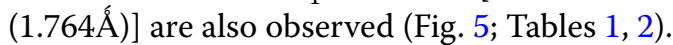

Comparing results from the computed model complexes 1, 2, 3 and the protein X-ray crystal structure, it is observed that energetically there is no difference between them, however, the $\mathrm{M}-\mathrm{O}_{1}[1.755 \AA$ (1.764 $\AA$ ) $]$ and $\mathrm{M}-\mathrm{OH}$ [1.990 $\AA$ (1.973 $\AA$ ) ] bond distances in model complexes
2 and 3, respectively, are similar to the metal oxo bond distance in X-ray crystal structure $(1.874 \AA$ ) (Tables 1 , 2 ). Based on the $\mathrm{M}-\mathrm{O}$ bond distance, the controversial oxo specie could most probably be the oxide group or hydroxide group. But when we compare the bond distances between metal center $\mathrm{M}$ and $\mathrm{S}$ of the dithiolenes, one $\mathrm{M}-\mathrm{S}$ bond is significantly longer than the other three in optimized model complexes $\mathbf{3}$ as well as in the protein X-ray crystal structure (Figs. 6, 7; Tables 1, 2). The elongation of one $\mathrm{M}-\mathrm{S}$ bond distance is due to the presence of high electronegative oxide group, in comparison to the sulfides, hydroxide and water molecules. Due to high electronegativity, shared electrons are attracted to the oxygen, resulting in a shift of electron density toward the oxide group, decreasing $\mathrm{M}-\mathrm{O}$ and increasing the $\mathrm{M}-\mathrm{S}$ bond distance. So, according to the computed results, this oxo specie is oxide (Fig. 8). 
Table 1 Geometrical features of the optimized model complexes of the reaction mechanism for the molybdenum containing nitrate reductase

\begin{tabular}{|c|c|c|c|c|c|c|c|c|}
\hline & $\begin{array}{l}\text { Crystal } \\
\text { structure }\end{array}$ & $\begin{array}{l}\text { Reduced } \\
\text { complex } \\
\text { 1a }\end{array}$ & $\begin{array}{l}\text { Oxidized } \\
\text { complex } \\
2 a\end{array}$ & $\begin{array}{l}\text { Oxidized } \\
\text { complex } \\
3 a\end{array}$ & $\begin{array}{l}\text { Reduced } \\
\text { complex } \\
4 a\end{array}$ & $\begin{array}{l}\text { Educt com- } \\
\text { plex } \\
\mathbf{5 a}\end{array}$ & $\begin{array}{l}\text { Transition } \\
\text { state } \\
6 \mathbf{6 a}\end{array}$ & $\begin{array}{l}\text { Product } \\
\text { complex } \\
7 a\end{array}$ \\
\hline Mo-S $1(\AA \hat{)})$ & 2.405 & 2.409 & 2.417 & 2.446 & 2.379 & 2.370 & 2.420 & 2.430 \\
\hline $\mathrm{Mo}-\mathrm{S}_{2}(\AA \hat{)})$ & 2.537 & 2.387 & 2.431 & 2.418 & 2.347 & 2.348 & 2.452 & 2.629 \\
\hline $\mathrm{Mo}-\mathrm{S}_{3}(\AA \hat{\AA})$ & 2.395 & 2.380 & 2.413 & 2.591 & 2.345 & 2.349 & 2.422 & 2.421 \\
\hline $\mathrm{Mo} \mathrm{S}_{4}(\AA)$ & 2.484 & 2.394 & 2.420 & 2.441 & 2.375 & 2.371 & 2.457 & 2.475 \\
\hline $\mathrm{Mo}-\mathrm{O}_{\mathrm{Asp}}(\AA \hat{)})$ & 1.97 & 2.142 & 2.145 & 2.083 & 2.017 & 2.029 & 2.102 & 2.133 \\
\hline $\mathrm{Mo}-\mathrm{O}_{\text {wat } / \mathrm{OH} / \mathrm{O} 1}(\AA \mathbf{)})$ & 1.874 & 2.335 & 1.990 & 1.755 & - & - & - & - \\
\hline Mo-O (Á) & - & - & - & - & - & - & 1.918 & 1.737 \\
\hline $\mathrm{O}-\mathrm{NO}_{2}{ }^{-}(\AA)$ & - & - & - & - & - & 1.310 & 1.723 & - \\
\hline $\mathrm{O}_{\mathrm{Asp}}-\mathrm{O}_{\text {wat } / 1}(\AA)$ & 1.596 & 2.428 & 2.458 & 2.684 & - & - & - & 2.786 \\
\hline $\mathrm{O}_{\mathrm{Asp}}-\mathrm{Mo}-\mathrm{O}_{\mathrm{wat} / 1}\left({ }^{\circ}\right)$ & 49.0 & 65.5 & 72.8 & 88.3 & - & - & - & 91.5 \\
\hline$S_{1}-S_{2}-S_{3}-S_{4}\left({ }^{\circ}\right)$ & -18.3 & -6.4 & 15.1 & -43.7 & -0.2 & 2.0 & 30.5 & 54.5 \\
\hline
\end{tabular}

a Water containing reduced complex

${ }^{\mathrm{b}}$ Hydroxide containing oxidized complex

c Oxygen containing oxidized complex

Table 2 Geometrical features of the optimized model complexes of the reaction mechanism for the tungsten containing nitrate reductase

\begin{tabular}{|c|c|c|c|c|c|c|c|c|}
\hline & $\begin{array}{l}\text { Crystal } \\
\text { structure }\end{array}$ & $\begin{array}{l}\text { Reduced } \\
\text { complex } \\
\text { 1b }\end{array}$ & $\begin{array}{l}\text { Oxidized } \\
\text { complex } \\
\mathbf{2 b}\end{array}$ & $\begin{array}{l}\text { Oxidized } \\
\text { complexc } \\
\text { 3b }\end{array}$ & $\begin{array}{l}\text { Reduced } \\
\text { complex } \\
\text { 4b }\end{array}$ & $\begin{array}{l}\text { Educt } \\
\text { complex } \\
\mathbf{5 b}\end{array}$ & $\begin{array}{l}\text { Transition } \\
\text { state } \\
\text { 6b }\end{array}$ & $\begin{array}{l}\text { Product } \\
\text { complex } \\
\text { 7b }\end{array}$ \\
\hline $\mathrm{W}-\mathrm{S}_{1}(\AA \hat{)})$ & 2.405 & 2.397 & 2.417 & 2.439 & 2.369 & 2.363 & 2.428 & 2.455 \\
\hline $\mathrm{W}-\mathrm{S}_{2}(\hat{\AA})$ & 2.537 & 2.377 & 2.423 & 2.432 & 2.334 & 2.335 & 2.419 & 2.442 \\
\hline $\mathrm{W}-\mathrm{S}_{3}(\AA \hat{)})$ & 2.395 & 2.373 & 2.414 & 2.549 & 2.337 & 2.337 & 2.424 & 2.562 \\
\hline $\mathrm{W}-\mathrm{S}_{4}(\AA \hat{)})$ & 2.484 & 2.388 & 2.412 & 2.424 & 2.371 & 2.369 & 2.457 & 2.428 \\
\hline $\mathrm{W}-\mathrm{O}_{\text {Asp }}(\AA \hat{)})$ & 1.97 & 2.122 & 2.113 & 2.040 & 1.980 & 1.986 & 2.079 & 2.076 \\
\hline $\mathrm{W}-\mathrm{O}_{\text {wat } / \mathrm{OH} / \mathrm{O} 1}(\AA \hat{)})$ & 1.874 & 2.286 & 1.973 & 1.764 & - & - & - & - \\
\hline W-O $(\AA ̊)$ & - & - & - & - & - & - & 1.942 & 1.757 \\
\hline $\mathrm{O}-\mathrm{NO}_{2}^{-}(\AA \hat{)})$ & - & - & - & - & - & 1.310 & 1.638 & - \\
\hline $\mathrm{O}_{\text {Asp }}-\mathrm{O}_{\text {wat } / 1}(\AA \hat{)})$ & 1.596 & 2.392 & 2.439 & 2.647 & - & - & - & 2.747 \\
\hline $\mathrm{O}_{\mathrm{Asp}}-\mathrm{W}-\mathrm{O}_{\mathrm{wat} / \mathrm{OH} / 1}\left({ }^{\circ}\right)$ & 49.0 & 65.6 & 73.2 & 87.9 & - & - & - & 91.2 \\
\hline$\left.S_{1}-S_{2}-S_{3}-S_{4}{ }^{(}\right)$ & -18.3 & -6.3 & 20.2 & -42.1 & 1.3 & 1.2 & 7.6 & -42.4 \\
\hline
\end{tabular}

a Water containing reduced complex

b Hydroxide containing oxidized complex

c Oxygen containing oxidized complex

\section{Optimized reduced complexes $4 a / 4 b$}

The reaction catalyzed by nitrate reductase is an oxotransfer reaction, in which an oxygen atom is transferred from nitrate to the reduced metal. As a consequence of the metal reduction from $\mathrm{M}^{\mathrm{VI}}$ to $\mathrm{M}^{\mathrm{IV}}$, the oxo group of the oxidized $\mathrm{M}^{\mathrm{VI}}$ is lost as hydroxo/water after proton uptake. Optimizations of the reduced active site model complexes $4 \mathbf{a}(\mathbf{4 b})$ without any additional ligand, i.e. fivefold coordinate metal center give $\mathrm{S}_{1}-\mathrm{S}_{2}-\mathrm{S}_{3}-\mathrm{S}_{4}$ dihedral angles of $-0.2^{\circ}\left(1.3^{\circ}\right)$, resulting in nearly tetragonal pyramidal geometries. The bond distances between the metal center $\mathrm{M}$ and $\mathrm{S}$ of the dithiolenes are reduced (Tables 1,2). The $\mathrm{M}-\mathrm{O}_{\text {Asp }}$ distance is reduced to $2.017 \AA$ (1.980 $\AA$ ).

\section{Optimized substrate complexes $5 \mathrm{a} / \mathbf{5 b}$}

First, nitrate gets loosely bound in the active site pocket by weak interactions with the active site residues $\mathrm{Asn}_{52}$ and $\mathrm{Gly}_{549}$ resulting in the substrate complexes 5a (5b) (Fig. 5). The computed reaction energies for the substrate complex formation are exothermic, $-9.6 \mathrm{kcal} /$ 


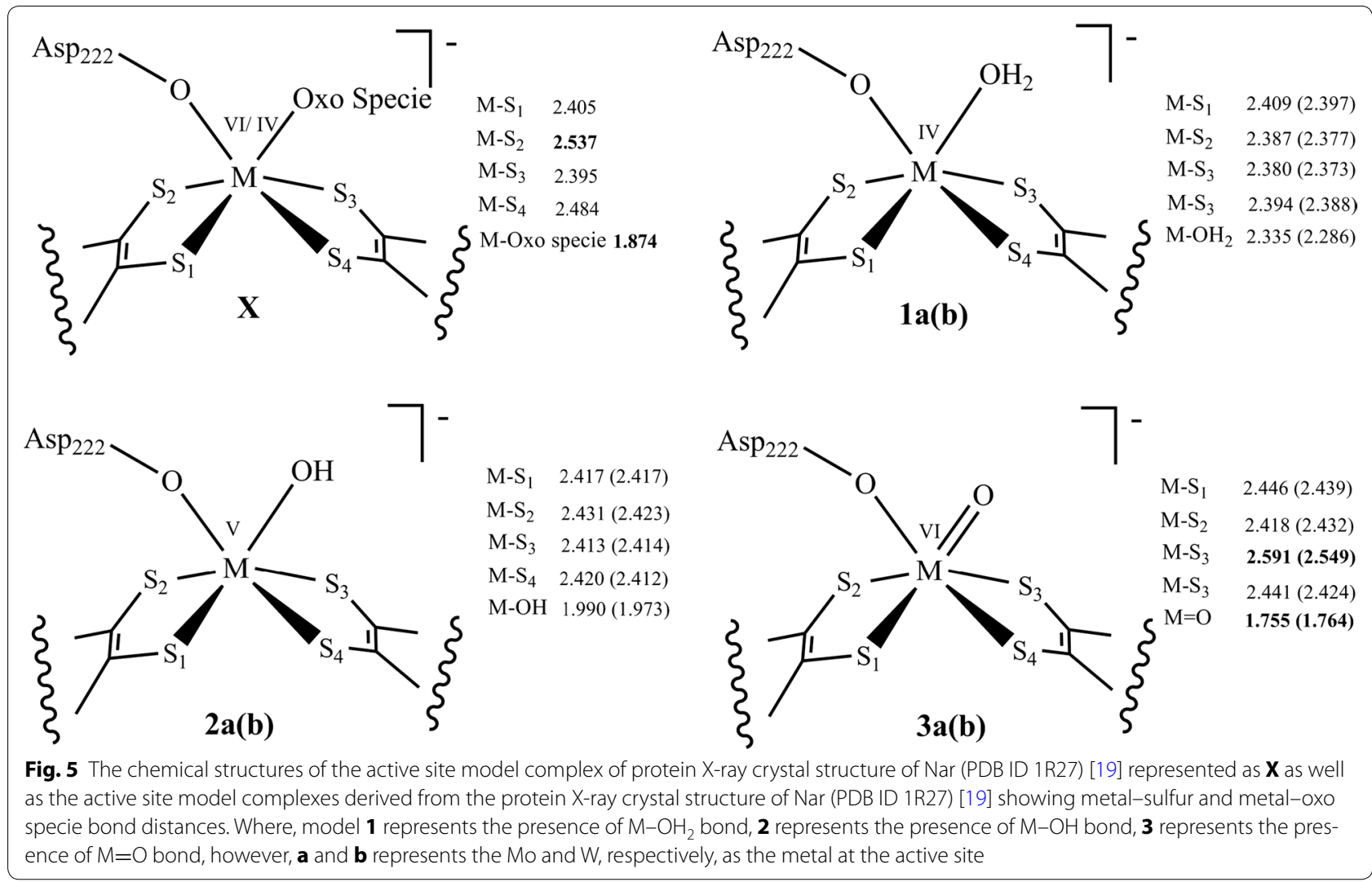

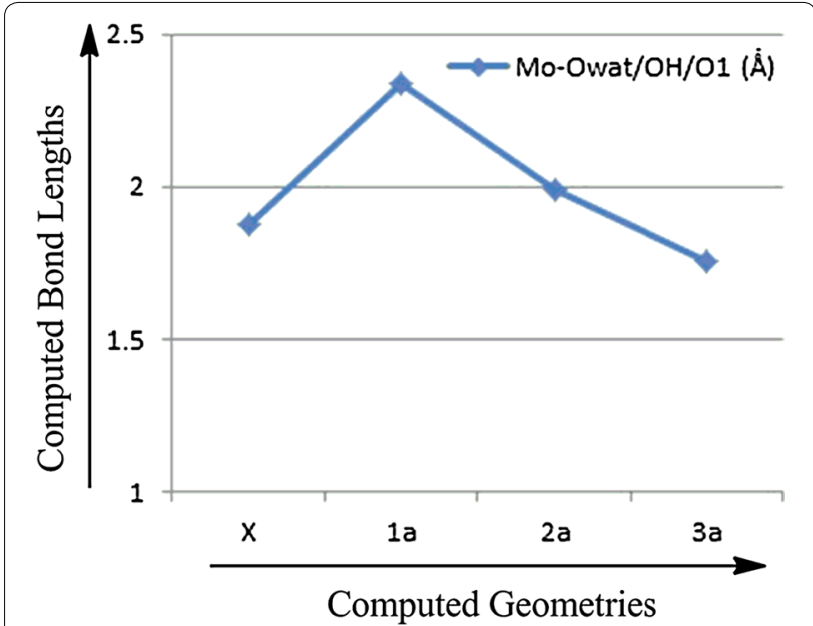

Fig. 6 Plot of crystallographic and computed metal-oxo species bond distances, where $X$ represents the experimental data and $1 a, 2 a$, 3 a represents the calculated data

$\mathrm{mol}(-7.6 \mathrm{kcal} / \mathrm{mol})$ in the gas phase and $-4.6 \mathrm{kcal} /$ $\mathrm{mol}(0.2 \mathrm{kcal} / \mathrm{mol})$ for the polarizable continuum model. There is no significant change in geometrical parameters of the active site relative to the reduced complexes $4 \mathbf{a}$ (4b) (Tables 1, 2).

\section{Optimized transition state complexes $6 \mathrm{a} / 6 \mathrm{~b}$}

Reduction of nitrate is a single step reaction in which the transfer of an oxygen atom proceeds through transition state $\mathbf{6 a}(\mathbf{6 b})$.The energy barrier computed for $\mathbf{6 a}$, $34.4 \mathrm{kcal} / \mathrm{mol}$ in the gas phase and $32.1 \mathrm{kcal} / \mathrm{mol}$ in the continuum, is almost three times as large as compared to that of $\mathbf{6 b}, 12.0 \mathrm{kcal} / \mathrm{mol}$ in the gas phase and $11.0 \mathrm{kcal} /$ mol in the continuum. There is also a remarkable difference in the geometries. The Mo containing transition state $(\mathbf{6 a})$ has a distorted octahedral geometry with an $\mathrm{S}_{1}-\mathrm{S}_{2}-\mathrm{S}_{3}-\mathrm{S}_{4}$ dihedral angle of $30.5^{\circ}$ and Mo-S bond lengths increased from $\sim 2.37$ to $\sim 2.45 \AA$ (Table 1 ). Mo-O and $\mathrm{O}-\mathrm{NO}_{2}$ distances are 1.918 and $1.723 \AA$, respectively. The Mo- $\mathrm{O}_{\text {Asp }}$ bond distance is elongated to $2.102 \AA$ Á.

The $\mathrm{W}$ containing transition state $(\mathbf{6} \mathbf{b})$ on the other hand has a distorted trigonal prismatic geometry where the $\mathrm{S}_{1}-\mathrm{S}_{2}-\mathrm{S}_{3}-\mathrm{S}_{4}$ dihedral angle is $7.6^{\circ}$. The W-S bond lengths are increased from $\sim 2.37$ to $\sim 2.45 \AA$ (Table 2). The $\mathrm{W}-\mathrm{O}$ and $\mathrm{O}-\mathrm{NO}_{2}$ bond distances are 1.942 and $1.638 \AA$, respectively i.e., $6 \mathrm{~b}$ can be considered to be an earlier transition state than 6a. The $\mathrm{W}-\mathrm{O}_{\text {Asp }}$ distance is elongated to $2.079 \AA$ Á.

In the optimized geometries $\mathbf{6 a}$ and $\mathbf{6 b}, \mathrm{NO}_{3}{ }^{-}$is coordinated to the metal at the active center and also forms a hydrogen bond to the $\mathrm{Asn}_{55}$. 


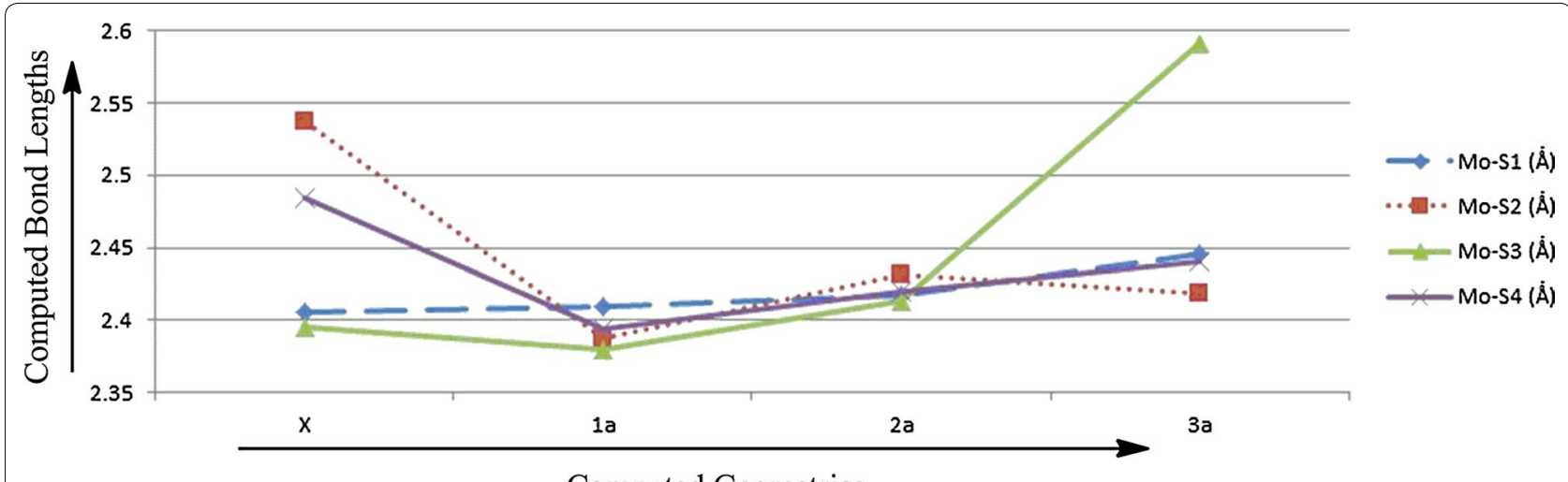

Computed Geometries

Fig. 7 Plot of crystallographic and computed metal-sulphur bond distances where $X$ represents the experimental data and $1 a, 2 a, 3 a$ represents the calculated data

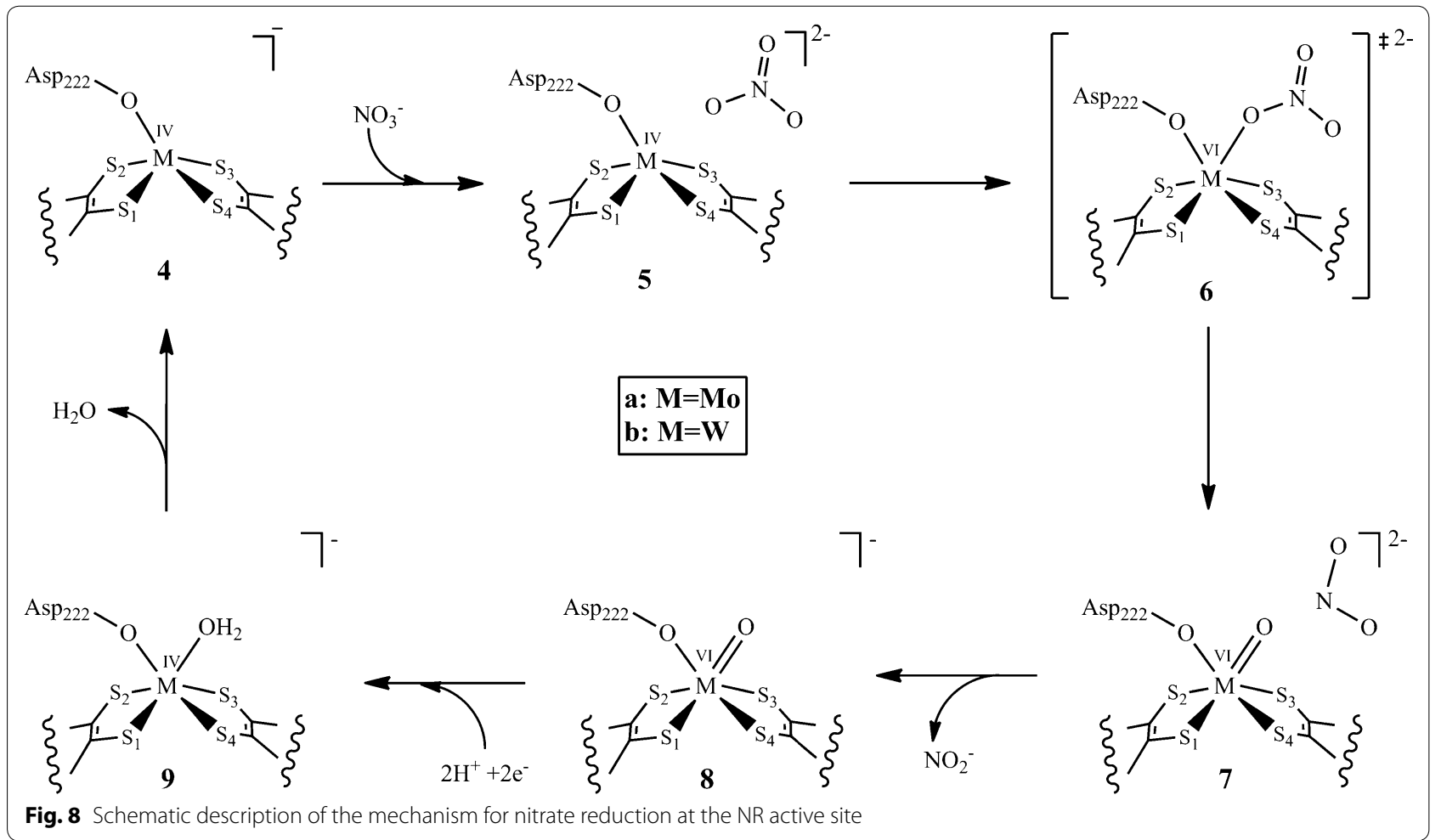

\section{Optimized product complexes $7 \mathrm{a} / 7 \mathrm{~b}$}

The nitrate reduction results in metal oxo product complexes $7 \mathbf{a}(7 \mathbf{b})$, having distorted octahedral geometries. In the optimized geometries, $7 \mathbf{a}$ and $\mathbf{7 b}, \mathrm{NO}_{2}{ }^{-}$is loosely bound in the active site pocket and make hydrogen bonds with the active site residues $\mathrm{Asn}_{52}$ and $\mathrm{Gly}_{549}$. Oxygen atom transfer is computed to be a slightly exothermic step for $\mathrm{M}=$ Mo where the product complex (7a) has a relative energy of $-7.6 \mathrm{kcal} / \mathrm{mol}$ in the gas phase and
$-1.9 \mathrm{kcal} / \mathrm{mol}$ in the continuum. The Mo-O bond distance is reduced to $1.737 \AA$ while the $\mathrm{O}-\mathrm{NO}_{2}{ }^{-}$bond is broken (4.444 $\AA$ ). The $\mathrm{S}_{1}-\mathrm{S}_{2}-\mathrm{S}_{3}-\mathrm{S}_{4}$ dihedral angle is further increased to $54.5^{\circ}$, the Mo-S bond distances are also increased to $\sim 2.629 \AA$ (Table 1). The Mo- $\mathrm{O}_{\text {Asp }}$ bond distance is further increased to $2.133 \AA$.

On the contrary, the $\mathrm{W}$ containing product complex (7b) is highly exothermic, with computed relative energies of $-43.3 \mathrm{kcal} / \mathrm{mol}$ in the gas phase and $-34.7 \mathrm{kcal} /$ 
mol in the continuum. The $\mathrm{W}-\mathrm{O}$ bond distance is reduced to $1.757 \AA$ while the $\mathrm{O}-\mathrm{NO}_{2}{ }^{-}$bond is broken $\left(5.133 \AA\right.$ ). The $\mathrm{S}_{1}-\mathrm{S}_{2}-\mathrm{S}_{3}-\mathrm{S}_{4}$ dihedral angle of the dithiolenes is decreased to $-42.4^{\circ}$, whereas the W-S bond distances are increased to $\sim 2.562 \AA$ (Table 2). There is no significant change in the $\mathrm{W}-\mathrm{O}_{\text {Asp }}$ bond distance (2.079 instead of $2.076 \AA$ ).

\section{Discussion}

To date, few archaeal Nars have been characterized from P. aerophilum [21], Haloarcula marimortui [43, 44] and Haloferax mediterranei [45]. These archaeal Nars contain Mo cofactors at their active sites. It is not clear how these microbes maintain their ability to respire with nitrate using Mo-containing Nar in a high temperature environment that is naturally enriched with $\mathrm{W}$ but depleted of molybdate $\left(\mathrm{MoO}_{4}{ }^{2-}\right)$ [46]. Early attempts to substitute tungsten for molybdenum in molybdo-enzymes failed because the organism was incapable of growing on the tungstate-containing medium [8]. However, the hyperthermophile $P$. aerophilum is a denitrifying archaeon requiring tungstate $\left(\mathrm{WO}_{4}{ }^{2-}\right)$ for growth although it's Nar is a Mo cofactor containing enzyme [20]. Afshar et al. [20] demonstrated that the external tungstate concentration affects the denitrification pathway efficiency of this archaeon, resulting in the complete denitrification only at high tungstate concentration.

Recently, Nar purified from P. aerophilum grown in the absence of added molybdate and with $4.5 \mu \mathrm{M}$ tungstate has been reported [13] which is a W containing enzyme. P. aerophilum $\mathrm{Nar}$ is the first active nitrate reductase that contains a W cofactor. The presence of a W cofactor may be reflective of high concentrations of this metal at high temperatures [40]. As previously described this enzyme can also accommodate Mo as the active site metal [21].

To compare the properties of Mo and W cofactors containing enzymes, DFT calculations were performed on the active site model complexes derived from the protein
X-ray crystal structure of $P$. aerophilum [19]. The crystal data shows that at the active site the metal is coordinated by bis-MGD ligands, a carboxyl group of $\mathrm{Asp}_{222}$ and an oxo specie. However, there is a controversy about the nature of oxo specie. Based on the optimized data from computed model complexes $\mathbf{1}, \mathbf{2}$, and $\mathbf{3}$, this oxo specie is most probably the oxide group.

The mechanism of nitrate reduction was also investigated using DFT calculations on active site model complexes containing Mo and $\mathrm{W}$ at the metal center. Nitrate reduction is an oxo-transfer reaction in which nitrate is reduced to nitrite and metal is oxidized from + IV oxidation state to + VI. The mechanism starts with the substrate binding with the metal center (Mo and $\mathrm{W})$ followed by oxygen atom transfer. According to the computed results, the computed energy barrier for the oxygen atom transfer from the nitrate to the metal center is $34.4 \mathrm{kcal} / \mathrm{mol}$ for the Mo active site model complex, about triple the energy barrier of the $\mathrm{W}$ active site model complex $(12.0 \mathrm{kcal} / \mathrm{mol})$ (Table 3$)$. Thus, as compared to Mo-Nar, W-Nar should be more active, which is in contrast to experimental findings [13]. However, the W-substituted DMSO reductase from the $R$. capsulatus was reported to be 17 times more active in the reduction of DMSO than the Mo-substituted enzyme [16, 18, 21], but, the W-substituted DMSO reductase was inactive for the oxidation of dimethysulfide (DMS) [46].

Oxidation of the educt complex is close to thermoneutral for the Mo active site model complex $(-1.9 \mathrm{kcal} /$ $\mathrm{mol}$ ) but strongly exothermic for the $\mathrm{W}$ containing active site model complex $(-34.7 \mathrm{kcal} / \mathrm{mol})$ (Table 3). It was anticipated that the low relative energy for the oxidized W metal complex makes the regeneration of the $+\mathrm{IV}$ oxidation state much more difficult as compared to the Mo metal complex, however, calculated results shows that $\mathrm{M}^{\mathrm{VI}}$ to $\mathrm{M}^{\mathrm{IV}}$ reduction for both $\mathrm{Mo}$ and $\mathrm{W}$ containing metal complexes requires equal amount to reductive power i.e., $140 \mathrm{kcal} / \mathrm{mol}$. So, although the

Table 3 Computed energies $(\mathrm{kcal} / \mathrm{mol})$ relative to the educt-substrate complex for the nitrate reduction

\begin{tabular}{|c|c|c|c|c|c|c|c|c|}
\hline & $\begin{array}{l}\text { Educt com- } \\
\text { plex } \\
\mathbf{4}\end{array}$ & $\begin{array}{l}\text { Substrate } \\
\text { complex } \\
5\end{array}$ & $\begin{array}{l}\text { Transition state } \\
\text { complex } \\
6\end{array}$ & $\begin{array}{l}\text { Product } \\
\text { complex } \\
7\end{array}$ & $\begin{array}{l}\text { Oxidized product } \\
\text { without nitrite } \\
3\end{array}$ & $\begin{array}{l}\text { Reduced prod- } \\
\text { uct with water } \\
\mathbf{1}\end{array}$ & $\begin{array}{l}\text { Reduced } \\
\text { product } \\
\mathbf{4}\end{array}$ & \\
\hline \multirow[t]{3}{*}{$M=M o$} & 0.0 & -9.7 & 30.2 & -11.6 & -36.0 & -151.5 & -142.0 & //B3LYPa \\
\hline & 0.0 & -9.6 & 34.4 & -7.6 & -49.1 & -141.0 & -125.7 & $S D D^{b}$ \\
\hline & 0.0 & -4.6 & 32.1 & -1.9 & 2.7 & -147.8 & -140.0 & $\cos \mathrm{MO}^{\mathrm{c}}$ \\
\hline \multirow[t]{3}{*}{$M=W$} & 0.0 & -7.8 & 7.0 & -52.6 & -36.3 & -150.3 & -142.0 & //B3LYPa \\
\hline & 0.0 & -7.6 & 12.0 & -43.3 & -27.7 & -139.1 & -125.7 & $S D D^{b}$ \\
\hline & 0.0 & 0.2 & 11.0 & -34.7 & -28.4 & -144.3 & -140.0 & $\cos M O^{c}$ \\
\hline
\end{tabular}

\footnotetext{
${ }^{a}$ B3LYP/Lanl2DZ(p)

b B3LYP/SDDp//B3LYP/Lanl2DZ (p)

c COSMO-B3LYP/SDDp//B3LYP/LanI2DZ(p) (see "Computational details")
} 


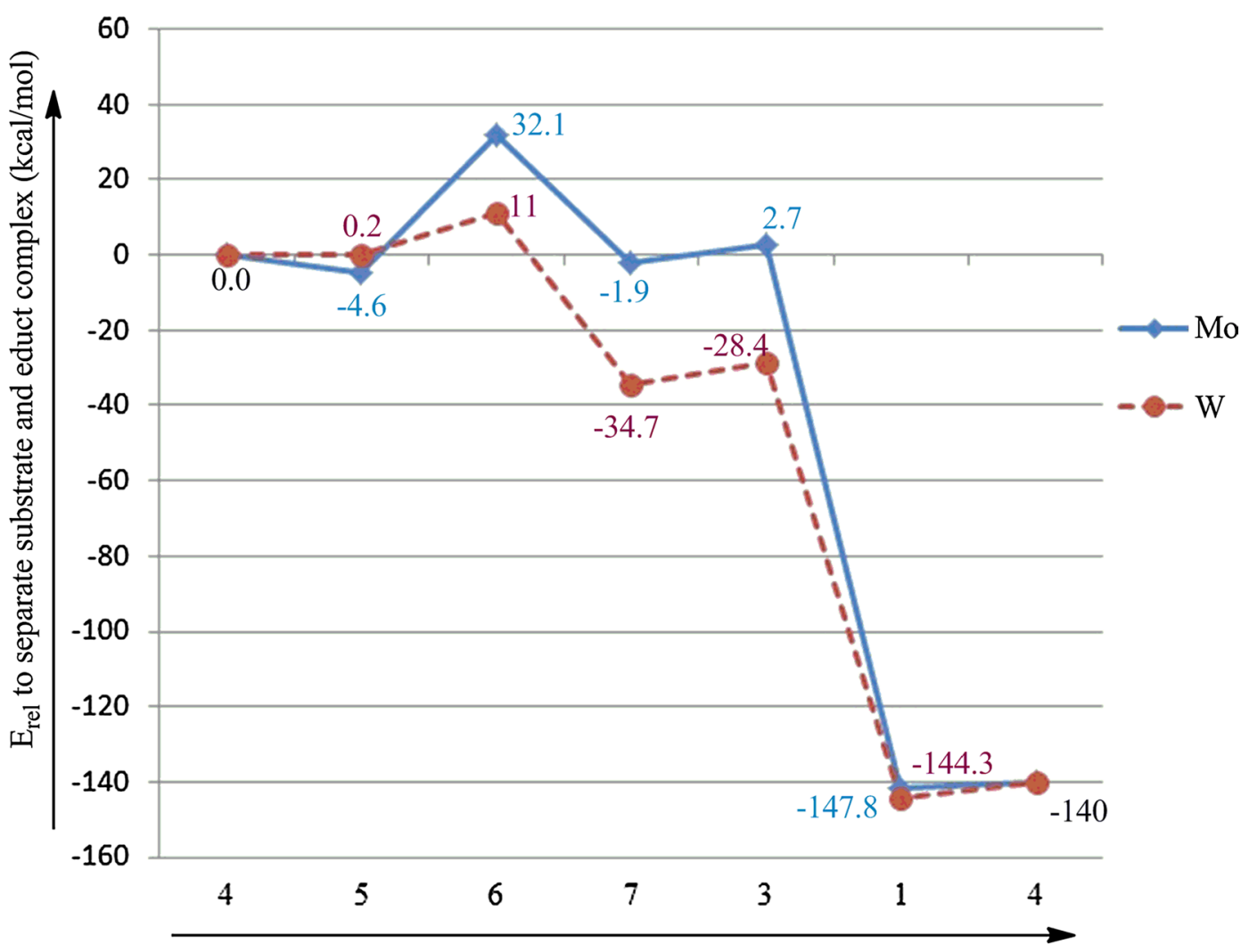

Reaction coordinates

where, $\mathbf{4}=$ educt complex, $\mathbf{5}=$ =educt-substrate complex,

$\mathbf{6}=$ transition state, $7=$ product complexwith nitrite,

$\mathbf{3}=$ oxidized product without nitrite, $\mathbf{1}=$ reduced product with water

Fig. 9 Plot of computed reaction energies ( $\mathrm{kcal} / \mathrm{mol}$ ) relative to educt complex vs steps involved in the reaction mechanism

reduction of nitrate is stimulated when $\mathrm{W}$ replaces Mo in the active site of Nar both the Mo containing Nar and $\mathrm{W}$ containing Nar requires the strong biochemical reducer (Fig. 9).

These results are in good agreement with the following experimental findings; (a) the hyperthermophile $P$. aerophilum is well adapted to a high-tungsten environment and this heavy metal is very important for its anaerobic growth mode on nitrate [21]. (b) In contrast to other mesophilic nitrate reducers, $P$. aerophilum growth with nitrate is not reduced/stopped at high tungstate concentrations [21]. Similar behaviour have been reported for NAD-dependent glutamate dehydrogenase enzyme in which enzyme isolated form hyperthermophiles shows comparable specific activities to those of enzymes from their mesophilic counterparts [47].

In conclusion, the computational result shows that the oxo specie attached with the metal at the active site of Nar is probably the oxide group. It is also concluded that the replacement of $\mathrm{W}$ with the Mo at the active site impart no effect on the overall reduction of nitrate except the energy barrier for oxygen transfer from nitrate which is low for W containing Nar (W-Nar). The most appropriate justification for this behavior of W-Nar is that P. aerophilum needs to support its growth by nitrate respiration even when the tungsten concentration in the environment is high; the same was concluded experimentally [21]. However, the reason for the activity loss of Nars with the increase in tungstate concentration in the environment needs to be further investigated (Additional file 1).

\section{Additional file}

Additional file 1. Supplementary material containing the Cartesian coordinates of all the optimized geometries.

\footnotetext{
Author details

${ }^{1}$ Research Center for Modeling and Simulation (RCMS), National University of Science and Technology (NUST), H-12, Islamabad, Pakistan. ${ }^{2}$ Institute of Inorganic Chemistry, Heidelberg University, Heidelberg, Germany.
} 


\section{Acknowledgements}

The author is highly thankful to Graduate Kollege 850 (GK-850) for financial support to complete this work.

\section{Competing interests}

The authors declare that they have no competing interests.

\section{Publisher's Note}

Springer Nature remains neutral with regard to jurisdictional claims in published maps and institutional affiliations.

Received: 10 August 2016 Accepted: 11 April 2017

Published online: 26 April 2017

\section{References}

1. Hille R (1996) The mononuclear molybdenum enzymes. Chem Rev 96(7):2757-2816

2. Johnson MK, Rees DC, Adams MW (1996) Tungstoenzymes. Chem Rev 96:2817-2840

3. Almendra MJ, Brondino CD, Gave O, Pereira AS, Tavares P, Bursakov S, Duarte R, Caldeira J, Moura JJ, Moura I (1999) Purification and characterization of a tungsten-containing formate dehydrogenase from Desulfovibrio gigas. Biochemistry 38:16366-16372

4. Hensgens $\mathrm{CMH}$, Hagen WR, Hansen TH (1995) Purification and characterization of a benzylviologen-linked, tungsten-containing aldehyde oxidoreductase from Desulfovibrio gigas. J Bacteriol 177:6195-6200

5. De Bok FAM, Hagedoorn PL, Silva PJ, Hagen WR, Schiltz E, Fritsche K, Stams AJM (2003) Two W-containing formate dehydrogenases $\left(\mathrm{CO}_{2}\right.$-reductases) involved in syntrophic propionate oxidation by Syntrophobacter fumaroxidans. Eur J Biochem 270:2476-2485

6. Hagen WR, Arendsen AF (1998) The bioinorganic chemistry of tungsten Struct Bonding 90:161-192

7. Stolz JF, Basu P (2002) Evolution of nitrate reductase: molecular and structural variations on a common function. ChemBioChem 3:198-206

8. Sigel A, Sigel H (2002) Metal ions in biological systems, vol 39. Marcel Dekker, New York

9. Cabello P, Roldan MD, Moreno-vivian C (2004) Nitrate reduction and the nitrogen cycle in archea. Microbiology 150:3527-3546

10. Richardson DJ, Watmough NJ (1999) Inorganic nitrogen metabolism in bacteria. Curr Opin Chem Biol 3:207-219

11. Campbell WH (1999) Nitrate reductase structure, function and regulation: bridging the gap between biochemistry and physiology. Annu Rev Plant Physiol Plant Mol Biol 50:277-303

12. Lin JT, Stewart V (1998) Nitrate assimilation by bacteria. Adv Microb Physiol 39:1-30

13. De Vries S, Momcilovic M, Strampraad MJF, Whitelegge JP, Baghai A Schröder I (2010) Adaptation to a high-tungsten environment: Pyrobaculum aerophilum contains an active tungsten nitrate reductase. Biochemistry 49:9911-9921

14. Zumft WG (1997) Cell biology and molecular basis of denitrification Microbiol Mol Biol Rev 61:533-616

15. Enoch HG, Lester RL (1972) Effects of molybdate, tungstate, and selenium compounds on formate dehydrogenase and other enzyme systems in Escherichia coli. J Bacteriol 110:1032-1040

16. Buc J, Santini CL, Giordani R, Czjzek M, Wu LF, Giordano G (1999) Enzymatic and physiological properties of the tungsten-substituted molybdenum TMAO reductase from Escherichia coli. Mol Microbiol 32:159-168

17. Brondino CD, Passeggi MC, Caldeira J, Almendra MJ, Feio MJ, Moura JJ, Moura I (2004) Incorporation of either molybdenum or tungsten into formate dehydrogenase from Desulfovibrio alaskensis NCIMB 13491; EPR assignment of the proximal iron-sulfur cluster to the pterin cofactor in formate dehydrogenases from sulfate-reducing bacteria. J Biol Inorg Chem 9:145-151

18. Stewart LJ, Bailey S, Bennett B, Charnock JM, Garner CD, McAlpine AS (2000) Dimethylsulfoxide reductase: an enzyme capable of catalysis with either molybdenum or tungsten at the active site. J Mol Biol 299:593-600

19. Jormakka M, Richardson D, Byrne B, Iwata S (2004) Architecture of $\mathrm{NarGH}$ reveals a structural classification of Mo-bisMGD enzymes. Structure 12:95-104
20. Afshar S, Kim C, Monbouquette HG, Schröder I (1998) Effect of tungstate on nitrate reduction by the hyperthermophilic archaeon Pyrobaculum aerophilum. Appl Environ Microbiol 64(8):3004-3008

21. Afshar S, Johnson E, de Vries D, Schröder I (2001) Properties of a thermostable nitrate reductase from the hyperthermophilic archaeon Pyrobaculum aerophilum. J Bacteriol 183:5491-5495

22. Chaudhry GR, MacGregor CH (1983) Cytochrome b from Escherichia coli nitrate reductase. J Biol Chem 258:5819-5827

23. Holm RH (1987) Metal-centered oxygen atom transfer reactions. Chem Rev 87:1401-1449

24. Jiang J, Holm RH (2005) Reaction systems related to dissimilatory nitrate reductase: nitrate reduction mediated by bis (dithiolene) tungsten complexes. Inorg Chem 44:1068-1072

25. Lee C, Yang W, Parr RG (1988) Development of the Colle-Salvetti correlation-energy formula into a functional of the electron density. Phys Rev B 37:785-789

26. Hay PJ, Wadt WR (1985) Abinitio effective core potentials for molecular calculations. Potentials for the transition-metal atoms Sc to Hg. J Chem Phys 82:270-283

27. Wadt WR, Hay PJ (1985) Abinitio effective core potentials for molecular calculations. Potentials for main group elements $\mathrm{Na}$ to Bi. J Chem Phys 82:284-293

28. Hay PJ, Wadt WR (1985) Abinitio effective core potentials for molecular calculations. Potentials for $\mathrm{K}$ to Au including the outermost core orbitals. J Chem Phys 82:299-310

29. Dunning TH, Hay PJ (1976). In: Schaefer HF III (ed) Modern theoretical chemistry, vol 3. Plenum, New York

30. Huzinag S, Andzelm J, Klobukowski M, Radzio-Andzelm E, Sakai Y, Tatewaki H (1984) Gaussian basis sets for molecular orbital calculations. Elesevier, Amsterdam

31. Andrae D, Haeussermann U, Dolg M, Preuss H (1990) Energy-adjusted ab initio pseudopotentials for the second and third row transition elements. Theor Chim Acta 77:123-141

32. Andrae D, Haeussermann U, Dolg M, Preuss H (1991) Energy-adjusted ab initio pseudopotentials for the second and third row transition elements: molecular test for $\mathrm{M}_{2}(\mathrm{M}=\mathrm{Ag}, \mathrm{Au})$ and $\mathrm{MH}(\mathrm{M}=\mathrm{Ru}, \mathrm{Os})$. Theor Chim Acta 78:247-266

33. Klamt A, Jonas V, Buerger T, Lohrenz JCW (1998) Refinement and parametrization of COSMO-RS. J Phys Chem 102:5074-5085

34. Barone V, Cossi M (1998) Quantum calculation of molecular energies and energy gradients in solution by a conductor solvent model. J Phys Chem A 102:1995-2001

35. Cossi M, Rega N, Scalmani G, Barone V (2003) Energies, structures, and electronic properties of molecules in solution with the C-PCM solvation model. J Comput Chem 24:669-681

36. Florsi F, Tomasi J (1989) Evaluation of the dispersion contribution to the solvation energy. A simple computational model in the continuum approximation. J Comput Chem 10:616-627

37. Florsi F, Tomasi J, Pascual-Ahuir JL (1991) Dispersion and repulsion contributions to the solvation energy: refinements to a simple computational model in the continuum approximation. J Comput Chem 12:784-791

38. Cammi R, Cappelli C, Corni S, Tomasi J (2000) On the calculation of infrared intensities in solution within the polarizable continuum model. J Phys Chem A 104:9874-9879

39. Pascual-Ahuir JL, Silla E, Tuñón I (1994) GEPOL: an improved description of molecular surfaces. III. A new algorithm for the computation of a solvent-excluding surface. J Comput Chem 15:1127-1138

40. George GN, Turner NA, Bray RC, Morpeth FF, Boxer DH, Cramer SP (1989) $\mathrm{X}$-ray-absorption and electron-paramagnetic-resonance spectroscopic studies of the environment of molybdenum in high-pH and low-pH forms of Escherichia coli nitrate reductase. Biochem J 259:693-700

41. McAlpine AS, McEwan AG, Bailey S (1998) The high resolution crystal structure of DMSO reductase in complex with DMSO.J Mol Biol 275:613-623

42. Cotton FA, Wing RM (1965) Properties of metal-to-oxygen multiple bonds, especially molybdenum-to-oxygen bonds. Inorg Chem 4:867-873

43. Yoshimatsu K, Iwasaki T, Fujiwara T (2002) Sequence and electron paramagnetic resonance analyses of nitrate reductase NarGH from a denitrifying halophilic euryarchaeote Haloarcula marismortui. FEBS Lett 516:145-150

44. Yoshimatsu K, Sakurai T, Fujiwara T (2000) Purification and characterization of dissimilatory nitrate reductase from a denitrifying halophilic archaeon, Haloarcula marismortui. FEBS Lett 470:216-220 
45. Martinez-Espinosa RM, Richardson DJ, Butt JN, Bonete MJ (2006) Respiratory nitrate and nitrite pathway in the denitrifier haloarchaeon Haloferax mediterranei. Biochem Soc Trans 34:115-117

46. Klenitz A, Adams MWW (1996) Tungsten in biological systems. FEBS Microbiol Rev 18:5-63
47. Kujo C, Ohshima T (1998) Enzymological characteristics of the hyperthermostable NAD-dependent glutamate dehydrogenase from the archaeon Pyrobaculum islandicum and effects of denaturants and organic solvents. Appl Environ Microbiol 64:2152-2157

\section{Submit your manuscript to a SpringerOpen ${ }^{\circ}$ journal and benefit from:}

- Convenient online submission

\section{- Rigorous peer review}

- Immediate publication on acceptance

- Open access: articles freely available online

- High visibility within the field

- Retaining the copyright to your article 